\title{
PHILOSOPHICAL THEOLOGY AND INDIAN VERSIONS OF THEODICY
}

\author{
VLADIMIR K. SHOKHIN \\ Moscow State University
}

\begin{abstract}
Comparative philosophical studies can seek to fit some Eastern patterns of thought into the general philosophical framework, or, on the contrary, to improve understanding of Western ones through the view "from abroad". I try to hit both marks by means of establishing, firstly, the parallels between Indian versions of theodicy and the Hellenic and Christian ones, then by defining to which of five types of Western theodicy the Advaita-Vedānta and Nyāya versions belong and, thirdly, by considering the meaning of the fact that some varieties of Western theodicy, like the explanation of evil by free will and Divine dispensation aiming at the improvement of man, have Indian counterparts while others lack them. Some considerations concerning the remainders of primordial monotheisms ("an argument from theodicy") under the thick layers of other religious world-outlooks are also offered to the reader at the end of the article.
\end{abstract}

\section{I.}

Quite recently, while participating in the First Asian Philosophy Congress in New Delhi (March 6-9, 2010 Jawaharlal Nehru University) and attending at the section on "Philosophy of Science", I was, at the end of some hot discussion, asked by the chair, what would be, in my opinion, the best advice to those who deal with comparative philosophy, a discipline which has always been in favour in India ${ }^{1}$. My answer was

${ }^{1}$ One should not forget that the very term "comparative philosophy" was introduced into English by the Indian historian of Indian sciences Brajindra Nath Seal in 1899, while comparisons between traditional Indian darśanas and Western philosophers in general (e.g., works of comparison between Buddhism or Vedanta and Kant, Whitehead, Bradley, Hegel, now also Husserl and Heidegger etc.) or between Western and Indian mysticism 
that, as is the case with all other sorts of rational activity, one embarking on comparative studies in philosophy, has also, first of all, in order to succeed, to determine for himself/herself what his/her endeavors should be for, because comparativistics for the sake of comparativistics (something that takes place often) lacks sense. In my opinion, the reasonable goals of comparative philosophy can fall into only two main types.

Comparative studies in philosophy may firstly be justified if one has in mind to use them as an instrument for the description and/or understanding of the concepts and doctrines of concrete texts from the Eastern philosophical tradition $X$ (which are "less transparent" for one) by means of the application to these latter of concepts and doctrines from Western traditions (that are "more transparent" for one). E.g., one aims at a better understanding of the famous and at the same time considerably enigmatic dualism of the ancient school of Sāňkhya-Yoga and acquires an idea of its specific features by comparing it with other versions of the same ontological pattern, like the mind-body dualism of Plato, Descartes or Kai Neilsen (saying nothing of Indian varieties of dualism in the shape of Jaina philosophy or the Vedāntic school of Madhva), or else by shifting the boundaries between "the objective" and "the subjective" spheres of being with Heinrich Rickert, or by means of the distinction between êtres en soi and pour soi presented by Jean Paul Sartre ${ }^{2}$. As a result of an investigation both of its similarities and dissimilarities with regard to other versions of dualism, the peculiarities of the Sānkhya-Yoga conception of the interrelations between "spirit" and "matter" turn out to be more understandable for one than they were before. But one can move also in the opposite direction, that is one can investigate one's "native" philosophical concepts or doctrines against the

and spiritual practices (e.g. between Rāmānuja or Vijňānabhikşu and St. Bonaventura etc.), both real and far-fetched, have always been in vogue in India. See, in particular: Encyclopedia of Indian Philosophies. Vol. I. Bibliography, ed. Karl H. Potter (Delhi: Motilal Banarsidass, 1995 - Third Revised Edition). Western-Indian parallels were also one of the main subjects at the First Asian Philosophy Congress (March, 2010) I referred to.

${ }^{2}$ All the parallels mentioned (with the exception of the one regarding Rickert) were discussed in: Gerald Larson, Classical Sāňkhya. An Interpretation of its History and Meaning (Delhi: Motilal Banarsidass, 1969), 229-238; Encyclopedia of Indian Philosophies. Vol. IV.: Sāňkhya A Dualist Tradition in Indian Philosophy, ed. Gerald J. Larson and Ram Sh. Bhattacharya ( Princeton, N.J: Princeton University Press, 1987), 74-77. 
background of their "foreign" counterparts, in order to widen the horizon of the former (as it is profitable sometimes to go abroad in order to better understand one's homeland), to fit them into an intercultural framework, to amplify their peculiarities and to make an estimate of them. While the comparativistic investigations in the direction "from West to East" have been justified from the beginnings of oriental studies, those "from East to West" needed to wait until the studies of Oriental philosophical traditions had reached a mature stage comparable in some degree with those of Western philosophy, as is the case in our time. Certainly, since our instruments for understanding non-Western traditions and their texts are also of the Western type, we have to revolve in a kind of the hermeneutic circle. But bearing in mind that "the boundaries of my world are those of my language", we have no choice but to proceed in this way, and this condition is not the worst one possible, insofar as scholars also of non-Western origin who wish to be understood in today's world accept it. My dealing with the topic of theology in connection with philosophy, as designated in the heading of this article, will be in the context of both of these types of comparative studies.

II.

But the heading itself, I believe, could justify these studies. It is not too common in the Anglo-American tradition to distinguish different fields within the discipline of "theology in connection with philosophy". Nevertheless, there is good sense in doing so, and it would be reasonable to outline from the first even the simplest difference between "genus" and "species". The genus I'd designate, for reasons of convenience, rational theology $y^{4}$. One of its species, from the Middle Ages entitled natural theology, can be, in my opinion, a component, in the strict sense, only of the Christian tradition. The reason is that Christianity emphasizes

\footnotetext{
${ }^{3}$ Prof. Richard Swinburne confirmed in our correspondence that there are no generally recognized precise definitions of such fields.

${ }^{4}$ The term theologia rationalis, as the opposition to theologia revelata, was popular in Europe in the seventeenth and eighteenth centuries. Cf. Kant's Kritik der reinen Vernunft (B 659-660, according to the standard mode of reference to the second edition of the text).
} 
more than any other tradition the gap between those religious truths which can be apprehended by human beings who, in Aquinas' terms, are led by the natural light of reason (ducti naturalis lumine rationis) and those attainable only through the light of Revelation ${ }^{5}$. But the term philosophical theology could be suitable for designating all traditions (Christianity included) where the existence of God, his attributes and actions in the world have been made a subject of philosophical reflection. E.g., it'd be ridiculous to call the Stoics or Epicurus "natural theologians", because they had no idea of Revelation (and, if they had, they would doubtlessly have rejected it), but they contributed much to the elaboration of philosophical arguments for the existence of a divine world and therefore delved into philosophical theology. Therefore philosophical theology may be designated as rational theology in the intercultural context, and its study could be very helpful for theistic-minded persons of different traditions today, as it was, e.g., in the Middle Ages, when exchange of opinions (not without polemics) did much for the theology in connection with philosophy of all the three monotheistic religions. That the reference point should be classical Western theism has nothing to do with any Eurocentrism, at least no more than the need for a gauge in any measuring, weighing etc. of material things implies a bias.

These purely theoretical assumptions receive some corroboration from practice. For example, I can refer to the newest and authoritative Oxford Handbook of Philosophical Theology edited by Thomas P. Flint and Michael C. Rea (Oxford University Press, 2009) where after four sections dealing with the main topics of rational theology the fifth one called "Non-Christian Philosophical Theology" includes material on the Jewish, Muslim and Confucian traditions. It is surely an unquestionable

\footnotetext{
${ }^{5}$ Thomas Aquinas, Summa contra gentiles, lib.1, c.3, cf. already Tertullian, Adversus Marcionem I.18 etc. The view that natural theology should deal only with arguments for the existence of God and analysis of Divine attributes (eternity, infinity, immutability, unity etc.), along with modes of their knowledge by natural reason, while the Christian dogmas are to be discussed in cursus theologici, was one of the cornerstones of the socalled second Scholastics who systematized the former. One may be referred to a text of such superb authority as Disputationes metaphysicae (chapter XXX) by Francisco Suarez (1597) as well as to the textbooks of his followers. See: Francisco Suárez, Opera omnia. Vol. 25-26 (Paris: Louis Vivés, 1856-1857), also Guiseppe S.J. Polizzi, Disputationes in universam philosophiam (Palermo, 1675-1676), disp. LIX-LX or Silvestro S.J. Mauro, Quaestionum philosophicarum (Roma, 1670), lib.V, quaest. 2.39-44.
} 
shortcoming that the editors didn't try to explicate their reasons for including under this rubric Confucianism, in which theistic elements were in the strict sense absent, and excluding Greek and Indian philosophers, among whom the former laid the foundations of almost all the types of arguments for the existence of God in Christianity, Islam and Judaism (enumerated in accordance with the comparative antiquity of "philosophy in connection with theology" in the three traditions) $)^{6}$ while the latter worked out different versions of the argument from design as well as such attributes as unity, eternity, omniscience etc., saying nothing about other things. Nevertheless, the very inclusion of non-Christian traditions in the volume under discussion is very appropriate for it widens the purview of different dimensions of philosophical theism, while the omissions under discussion stimulate more careful work in this direction.

The history of the term 'philosophical theology' itself, in the strict sense, dates from Thomas Aquinas' Exposition super librum Boethii De trinitate (commentary to Boethius' treatise on the Holy Trinity - 12578) where "the divine science" is divided into theologia sacrae scripturae and theologia philosophica; in the latter God is to be known by means of natural reason. But a separate discipline of knowledge under this title is not older than the two-volume book by Frederic Robert Tennant Philosophical Theology (1928-1930) ${ }^{7}$. In either case philosophical theology is by definition a bipartite area of knowledge. As a field of philosophy it corresponds to a self-sufficient investigation of metaphysical realities to which God with his attributes and actions pertains as a special and crucial subject. As a kind of theology it aims at the acquisition of certain spiritual goals, the polemical assertion of faith against militant unbelief being one of the most important means towards this.

What corresponds to philosophical theology in the Indian tradition and constitutes the topic of this investigation was called iśvaravāda

\footnotetext{
${ }^{6}$ It is well-known that the argument from design goes back to Plato and the Stoics, the cosmological argument to Plato and Aristotle, the argument from the fact that religion is widespread in all of mankind to Plato and Epicurus, that from religious experience to the Stoics who also reasoned that the most perfect being has to exist because of "the ladder of perfections" in the world, an argument wherein a prototype of Anselm's ontological argument is recognizable.

${ }^{7}$ See: Frederic Robert Tennant, Philosophical Theology. Vol. 1-2. (Cambridge: Cambridge University Press, 1928-1930).
} 
("the teaching that Ísvara, or the Lord, exists"). Both metaphysical and polemical components were interrelated also in this case, but the polemical bias here was still weightier than in the West, because from the early Middle Ages up to the Enlightenment Western theism didn't face real opponents while in India theistic attitudes of thought met very strong opposition from the very beginning. Indian philosophical theists had to defend many outposts against stubborn enemies, or followers of niriśvaravāda ("the teaching that İ́vara, or the Lord, does not exist") who tried to assert the incompatibility between the power of the Lord and human responsibility, between an incorporeal God and the material world, between Divine aims in the world and Divine self-sufficient being.

The problem of evil has always been the sharpest point of controversy in both West and East, because the real (though not insurmountable) difficulties in reconciling the idea of Divine goodness, omniscience and omnipotence with the abundance of suffering and evil in the world (for which God has to have responsibility) have always been the trump card of all antitheists including those of India. But before embarking on Indian attempts to overcome "the argument from evil" let us obtain a bird's-eye view of the main historical versions of Western theodicy.

III.

The main historical versions are well-known and with a view to comparison one may confine oneself to their general classification in the context of anti-theistic arguments (their spectrum being related to atheistic ones as the whole to the part) arising from the problem of evil to which they have responded.

Western antitheistic arguments may be divided into (1) "dogmatic" endeavors merely to disprove the existence or activity of God in the world on the ground of the abundance of evil and (2) "sceptical" doubts concerning the cogency of the main rational ways of reconciling His existence with this abundance. I would designate (1) as a naturalistic position and (2) as a critical one. To (1) belong the following: those characters from Plato's Laws (book 10) for whom the fact that the impious live to a venerable age, enjoy honors and transfer them to their 
offspring were proofs of the inactivity of the gods in the world; Epicurus, to whom is ascribed the famous slogan that if the divine being is willing to prevent evil, but not able, then it is impotent, if is able but not willing, then malevolent, but if is both able and willing, then whence comes evil?; Voltaire, for whom the Lisbon earthquake that took many lives was a good argument against God's responsibility for the world (in accordance with his general deistic views); John L. Mackie, who insisted that a theist has to believe both that God exists and that evil exists but cannot do so consequently, and many others. While the majority of naturalists emphasize the unworthy tolerance of evil on the part of a being whom theists consider to be God, some of them (1a) also accuse Him of consciously assisting evil. An example is given by Anthony Flew who charges Him with not having conferred on men powers to carry out only righteous choices and actions in order to avoid at least a large amount of evil. Among the most notorious representatives of (2) one may mention the following: Pierre Bayle who rejected the very possibility of reconciling faith with reason in relation to the existence of evil in the world created by God; David Hume who, on the one hand, approved of Epicurus (see above) and wondered how God's infinite power and wisdom might be compatible with the sufferings of men, animals and the whole of nature (where no one is lucky), but, on the other hand, rejected only the theistic image of a personal God as anthropomorphic but not the idea of God as such and underscored its incomprehensibility; William Rowe, who rejects the idea of understandable goods behind gratuitous sufferings and deaths (like the death of a fawn in a forest fire ${ }^{8}$ ) and offers to regard the problem from the perspective of "friendly atheism". I consciously juxtapose here ancient, modern and contemporary philosophers because it is in the nature of philosophy (and this distinguishes it from the sciences) to reproduce the same decisions on the same perennial issues during centuries and even millenniums, with only the techniques of discussion differing.

The same is true also for the main patterns of theodicy which are not too numerous and also present certain perennial archetypes. While the anti-theistic positions could, I believe, be generalized, in contemporary

\footnotetext{
${ }^{8}$ Such tender sensitivity for the sufferings of animals, not of men, is very typical of the age when the love of many shall wax cold (Matthew 24: 13). Here and below references to the King James Bible are made.
} 
terms, as affirming incompatibilism in regard to the interrelation between the Divine attributes and the fact of evil in the world, the theistic ones correspond to compatibilism in the same context. Four of them have a long pedigree (three among them have followers today), while the fifth one (as a well-reasoned position) is very new.

Pattern (1) may be designated as the attempt to defend the compatibility between the existence of an omniscient, omnipotent and omnibeneficent God and the abundance of evil, by the virtual elimination of the latter as something which is, in the final analysis, a result of our misunderstanding of the world and, consequently, a nonessence having only a semblance of being. Among the most notorious champions of this view (here, as also in the following cases, their sorting will be very selective) were the following: the Stoics who interpreted evil as a product of the deficiency of our knowledge; Plotinus, who regarded evil as either a product of matter which is almost the same as non-being, or only a diminution of good (cf. Enneades I.8 and III.2.5); Origen, for whom evil was something nonexistent, because everything existent must be created by God and God could not create what contradicted his own nature (Commentary to Gospel according to John II,13,93); St. Basil the Great and other Cappadocians for whom evil was nothing in its essence and something in between an "ontological parasite" and a pure appearance; Pseudo-Dionysius, who emphasized, by means of his famous method of negations, that evil is outside any way, goal, nature, causes, beginnings, ends, limits, forms and even the existence of anything ( $D e$ divinis nomonibus IV. 20-23); Johannes Scotus Eriugena who was sure that God doesn't know evil which, therefore, doesn't exist; Aquinas, who elaborated this privative conception of evil as something which is neither existent nor nonexistent in accordance with Boethius' conception that the notions of good and being are mutually convertible (Summa Theologiae II,2, qu.18, a.132); and lastly Leibnitz, who also adopted the privative conception of evil and approved such aphorisms as malum causam habet, non efficientem, sed deficientem (Essais de Theodicée I.20). One may be sure that the opposition to Manichean dualism (where cosmic evil enjoyed almost the same rights as good) and the indirect reception of Neoplatonic ontology (cf. the interpretation of matter as being more the privation than the possession of something and as a kind of middle 
between existence and nonexistence) were important resources for the elaboration of this sort of theodicy on the side of Christian theologians.

According to pattern (2) evil is not something ontologically defective, but, on the contrary, a necessary element of the world system and its universal harmony and order. Here Plotinus is to be remembered, inasmuch as, according to his reasoning, since only God can occupy the highest step on the ladder of being and all the others also have to be occupied, including the "ground-floor", evil is inevitable, while those who would like it to be eliminated are similar to those ignorant critics who rebuke an artist for not using one color, a producer for including also negative characters into his play and citizens for establishing the service of an executioner (Enneades III.2.12.9; III.2.17.83); St.Augustine, who reproduced the analogy of the executioner, adding to it that of the cithara (different strings produce different sounds and not only high but also low ones) and formulated the famous principle that God by means of His omnipotence can make good out of any evil and, therefore, the lack of many evils would have led to the absence of numerous goods (De ordine II.4.12); Aquinas, for whom the perfection of the universe entails inequality of things and, hence, that in order that all niches of the good should be occupied there should also be things deviating from the good; Bonaventura (Commentaria in libros IV Sententiarum I.1.d.44, a.1, qu. 4 ) and Ulrich von Strassburg (Summa de bono II.3.4), for whom, correspondingly, a white picture can be perfect only with the addition of black, and the punishment of sinners facilitates the beauty of Divine justice and rulership in the world. But, certainly, Leibnitz is here the chief character as a mouthpiece of the view that while the reason for evil may be regarded as necessary, its origin is an accident, while the harmony of things implements its transition from possibility to reality because of its appropriateness in this "best of all worlds" (Causa Dei, \$68-69). Among his contemporary followers Nelson Pike and Roderick Chisholm are to be selected, because of their opinion that evil is a necessary element of the world's harmony and order.

Pattern (3) is in line with the treatment of the origin of evil in a free and false will. Here the following may be mentioned: Plotinus again with his view that evil is a result of the free choice of the outward life instead of contemplation of the spiritual world; Proclus whose opinion was that the egoistic self-isolation of finite souls from the cosmic whole 
and each other was the cause of their inner discord leading to their ruin; Origen (cf. Contra Celsus III.69; IV.12, 20, 21, 64 and De principiis II.6.4-6), for whom men become evil because of bad upbringing, free self-corruption and vicious environment, even to such a degree that vice becomes a component of their nature, and moral evil becomes the cause even of physical disasters in nature (though some of them are produced by demons); Tertullian, who formulated very clearly the view that the cause of evil is not God but only the abuse of freedom, which in itself is the greatest gift of God to man, while Divine interference into free choice would have been contradictory to God's own good will and stated that one has to distinguish between evil as sin that depends wholly on man and evil as punishment that comes from Divine justice aiming at the restoration of sinners (Adversus Marcionem II.6, 15-16); St. Basil the Great and St. Augustine with their clear view that it was humans and not God who made the perverted choices, and that the nature of evil depends on what humans constitute (so sinfulness is not a substance but perverted will which rejects "the inner man" and involves "getting firmly established in the outward world"), this view being followed by Pseudo-Dionysius and Eriugena; Aquinas, for whom also it was clear that God was the creator of only such evil as is involved in punishment but by no means of that which is involved in guilt; Leibnitz who stated that had God deprived man of the very possibility of misusing his free will, it would have been something still worse than sin itself. Today, Alvin Plantinga vindicates free will theodicy and renovates it in terms of possible worlds and "transworld depravity", while Eleonore Stump undertakes a more traditional defence of this type of theodicy based on the traditional difference between moral and physical evil (dating back, as we know, to Terullian). But, one way or another, the free will theodicy is shared by all well-known theists for whom the dogma of the Fall is of any significance.

Pattern (4) is called the soul-making defence, in other words, the account of evil as Divine dispensation aiming at the improvement of man. Here the following may be mentioned: Plotinus, again, who considered

${ }^{9}$ St. Basil's opinions might be selected from Patrologia Graeca 31, 332-333,344,348, while the locus classicus of St.Augustine's opinion is Confessionum libri tredicum (The Confessions) VII.12.18. 
evil as a means to help humans in increasing vigilance, waking sound reason, withstanding obstacles and realizing how beneficent virtue is in comparison with the disasters which befall wrongdoers (Enneades III.2.5.15); Tertullian again (Adversus Marcionem II.16) and Origen (cf. Contra Celsus VI.56 and Philokalia 27, 7) who were sure that Divine punishments were similar to bitter drugs used by doctors on recovering patients and that every suffering was intended not against those who suffered but for their good; again Pseudo-Dionysius who insisted that Providence used evil for the profit of humans, be it individual or social. Among today's champions of this version of theodicy John Hick and Richard Swinburne are the most distinguished. The former defends what he calls St. Irenaeus' theodicy ${ }^{10}$ and insists that in order to make right choices humans have to be provided, besides free will, also with some environment that could help them to develop their characters, firstly by relieving the suffering of others, and for that suffering itself should take place. Swinburne's view is that in order that some good beliefs of man implanted into him by God should not only be acknowledged by him, but also "learned", man has to be placed in certain conditions leading him to practical moral training and the latter is unfeasible without certain evils (both moral and physical) which could secure outweighing goods.

What I consider to be the newest pattern (5) is less definite than those discussed above. It may be called a defense from the limits of human knowledge or as a contextual theodicy. For example, when answering to Rowe's account of "gratuitous sufferings" Peter van Inwagen appeals, on the one hand, to free will, and, on the other, to the possibility that God has His own accounts of the magnitude, duration and distribution of evils which are simply inaccessible for human minds (in opposition to epistemologically optimistic versions of theodicy) but are not lacking. Michael Murray's conception of God's hiddenness is also in some sense in this vein. Close to this reasoning is Marilyn Adams' "theistic agnosticism" according to which we can have no idea why some "horrors" (whose "volume" outweighs what we could regard as "superior goods") are dispensed and may only hope that some strategies of understanding

${ }^{10}$ Unfortunately, Hick doesn't provide, according to my knowledge, his readers with references to St. Irenaeus' text, considering that his "general considerations" should be quite sufficient for them. 
could be helpful here, but they should be different from "the traditional theodicies". Robert Adams' conception of "individual theodicies" by which every one may propose Providence in one's own personal life without submitting it under some or other kind of "general theodicy" is also of the type under discussion.

However crude and selective the portrayed "map" of Western theodicies is, it justifies some generalizations. First, all the patterns of theodicy, with the exception of (1) which has become part of the heritage of philosophical theology, have followers today, while (5) is an immediate result of contemporary discussions. Second, with the exception of a few names, the same thinkers of the highest authority in the subject (Plotinus, Tertullian, Origen, St. Augustine, Pseudo-Dionysius, Eriugena, Thomas Aquinas, Leibnitz) didn't confine themselves within a single strategy of theodicy, but felt the need to combine several patterns, presenting a kind of a "cumulative case", and the same is true also with contemporary theistic philosophers. The reason is very transparent: the explanation of the abundance of evil in the theistic context (I mean the context of the main Divine attributes) is anything but easy philosophical entertainment, and evil itself is by no means a "one-dimensional" reality, hence, in this context, different approaches to its understanding seem justifiable. Indeed, some of them may be regarded as mutually complimentary, as, e.g. (3) and (4). Third, like everything in philosophy (let's not forget that philosophical theology at least partly belongs to philosophy), the strategies of explaining evil against the background of a theistic worldoutlook may also be differentiated as more and less persuasive. Pattern (1) is not persuasive because it contradicts the general and, moreover, everyday human experience which leaves no doubt in any soul that evil is very real and by no means "a mere semblance of being". It is true that when we sin against anybody we may have an illusion that he (she) makes a mistake in identifying our action as evil, but when someone sins against ourselves we have not the least doubt that evil is done. In addition, in spite of all justification in regarding evil as "non-being" in the context of the controversy against Manicheism (and its branches) Christian authors (even those of great authority) obviously did contradict both Scripture (cf. Ephesians 2:2, 6:12), where the forces of evil are depicted as a most vital and active reality with which a battle to the death is recommended 
as the necessary condition of salvation ${ }^{11}$, and the whole ascetic tradition. Pattern (2) is in contradiction with logic, because any 'evil' which is a necessary component of the cosmic perfection and harmony would not be an evil, but an obvious good, and it is surprising that such an outstanding philosopher as Leibnitz didn't notice this. Again, this view is unnatural for the Christian world-outlook (while this is not the case with Neoplatonism which didn't have the concept of $\sin ^{12}$ ): the difference between good and evil is by no means the same as that between different colors and tunes, and it is surprising again that such great theologians as St. Augustine and Bonaventure didn't understand this. Patterns (3) and (4) are much more persuasive, for almost everyone who has a conscience can feel in the depths of his "inner man"13 that there is or has been a connection between his (her) choice of evil and some suffering in his (her) life. On the other hand, one cannot be sure that one's suffering may be fruitful for one's spiritual improvement. Nevertheless, sufferings differ. I can realize, e.g., that some physical (or even mental) injury, or poverty, or injustice etc. may be of some (or even much) profit for me, but it is surely a mystery for me what greater good may follow for a newborn baby perishing in a crushed aircraft, or for his parents washed away by a tsunami, or for pious parishioners who perish right in a church because of an earthquake, or for victims of terrorist attacks in an underground railway. In this regard pattern (5) has an advantage because it leaves more space for humility in reasoning (and this is a crucial Christian virtue) than other versions do, and this is in a better accordance with a genuine theistic world-view which entails that the reasons of the Creator are not always comprehensible for the minds of even the most reasonable creatures because of the ontological gap between Him and them ${ }^{14}$.

${ }^{11}$ The same war is recommended against sin which has become almost the second nature of man (cf. Romans 7: 15-17 and Hebrews 12:4), and what we have to battle against cannot be regarded as a "semi-being".

12 Though the Platonists knew the words amartia and amartêma, the question with them is not about "sins" in the real sense but about "mistakes", or disrepair of the soul.

${ }^{13}$ See: 2 Corinthians 4:16, Ephesians 3:16, cf. 1 Peter 3:4.

${ }^{14}$ Cf.: Or those eighteen, upon whom the tower in Siloam fell, and slew them, think ye that they were sinners above all men that dwelt in Jerusalem? I tell you, Nay: but, except ye repent, ye shall all likewise perish (Luke 13: 4-5). 
IV.

The scheme depicted provides coordinates for the accommodation also of non-Western counterparts of theodicy, which is in line with the main tasks of philosophical theology as a cross-cultural reality (see above). Here the anthology, edited by Eleonore Stump and Michael J. Murray (Blackwell, 1999), might be referred to. In the section "Doesn't all the evil in the world show that there is no God?" two passages from, correspondingly, Muslim and Jewish texts are included, along with contemporary Western texts on theodicy, which do really correspond to two of the abovementioned patterns, though the editors themselves didn't aim at classification. The first one, taken from one of the most authoritative Muslim theologians and philosophers Al-Ghazali (1058-1111), is an attempt to explain the existence of evil in "the best of all possible worlds". In line with Plotinus, St. Augustine, Ulrich von Strassburg and Bonaventure, he justifies evil as a necessary component of the world, "for were it not for night, the value of day would be unknown. Were it not for illness, the healthy would not enjoy health. Were it not for hell, the blessed in paradise would not know the extent of their blessedness", and, as Al-Ghazali emphasizes, "every lack in the next world in relation to one individual is a boon in relation to someone"15. Beasts have been created in order that the dignity of man might be manifest and favors for the inhabitants of paradise are increased by increasing the punishments for the inhabitants of hell ${ }^{16}$. Doubtless, we have here pattern (2) of theodicy in its clearest form, and the objections against it remain valid. The main objection is that an 'evil' which is both necessary and beneficial for the world is not evil, but good. But insistence on the instrumentality of the punishment of sinners with regard to the glory of the saints is also tantamount to the acknowledgement that God, being desirous of the second, should be interested also in the first, and is, consequently, at least an indirect cause of moral sin. By contrast, a passage from the distinguished Jewish theologian Saadya Gaon (882/92 -942) leaves no doubt that his version of theodicy is very close to pattern (3). While questioned how it is possible that there should exist in God's world anything which does not find His approval, he unhesitatingly

${ }^{15}$ This seems to suppose that the Master of boons is "restricted" in His means.

${ }^{16}$ Philosophy of Religion: The Big Questions, ed. Eleonore Stump and Michael J. Murray (Blackwell publishers Inc., 1999), 190-191. 
refers to human free will, stressing that God abhors human disobedience for our own sakes because it has a harmful effect on us. Though Saadya Gaon does not state directly that for God our free will is so valuable that He prefers its misuse leading to evil in the world and the suffering of human beings to depriving His creation of it, his arguments for the existence of free will express this idea ${ }^{17}$.

But why should we confine ourselves with anthologies? The newest translation of Ibn Rushd's (1126-1198) trilogy constituting what is called Exposition of Religious Arguments leaves no doubt that his conception of "evil for the sake of good" can also be placed into the context of the same patterns. According to the "most subtle" Muslim philosopher, "since leading astray is evil, and since there is no creator beside God, it was necessary to attribute that to Him, just as the creation of evil is too. However, this must not be understood in an absolute sense because He is the Creator of the good for its own sake and the Creator of the evil for the sake of the good; I mean for the sake of the good that is conjoined to it. On this view, God's creation of the evil could be just". Ibn Rushd gives the example of fire which is necessary for the subsistence of many things and despite the fact that it might accidentally destroy some existing things, its existence on the whole is much better than its non-existence, and thus it is good ${ }^{18}$. Without doubt this explanation of evil belongs mostly to pattern (2), though some "tunes" of pattern (4) are also heard in it.

The same scheme of fitting Eastern versions of theodicy into the main patterns discussed above will work also in the Indian case. But one important difference is to be mentioned from the start. Medieval Muslim and Jewish elaborations of the topic are based on discussions of the earlier Mutakalims (viz. "theologians'), i.e. Mu'tazilites who from the eighth century A.D. tackled, among other issues, whether God has power over the evil deeds and injustices of His reasonable creatures. They also discussed whether God has power over the human choice of actions itself. These controversies were serious and sometimes even heated, but they were located in the "inner circle" of theistically-minded participants. In India, in contrast, the problem of evil had been launched by militant

${ }^{17}$ Ibid., 193-194.

${ }^{18}$ Faith and Reason in Islam: Averroes' Exposition of Religious Arguments. Averroes. Transl. with footnotes, indices and bibliography by Ibrahim Y.Najjar with an introduction by Majid Fakhry (Oxford: One World, 2007), 118-119. 
anti-theists for whom the very idea of God was hateful. Enemies of a God who tolerates evil and suffering in the world that has something to do with Him, were more powerful and active in India than even in the West and, one more important thing, were active right from the earliest stages of theistic philosophizing. This justifies a separate digression concerning the anti-theistic stress on the incompatibility between the Divine attributes and the abundance of evil in the world.

V.

It was not later than in the Pali Jätakas that the argument from evil was implemented by the Buddhists, their main emphasis being on the incompatibility between belief in Brahma as the lord (issaro) of the world and the unhappiness and unrighteousness found in the latter (VI.208) ${ }^{19}$. In the Madhyamika text Dvadashamukha ("Twelve Gates"), preserved in a Chinese translation (circa the fourth century A.D.), the Buddhist replies to a theistically-minded opponent that had these creatures been Íśvara's children, he would have taken care to use enjoyment to eliminate suffering, and this is unobservable in any way, even with regard to those who revere him. In his auto-commentary to his famous Abhidharmakosha Vasubandhu (of the same period) brings up the question what could be the real aim of İ́vara (assuming he exists) in organizing the universe. If it were for the fulfillment of his own desires and needs, he cannot be its "Lord" (i.e. İ́vara), but if he is just fond of creating human beings subject to sufferings in hells, etc., then "my humble respects to such an İ́vara!" (II.63-64). The same sarcastic question is posed in the extensive critical commentaryon Sanghabhadra's Abhidharmakośa-bhāşya (conventionally called "Nyāyānusara", dating to the late fourth century A.D.), where the Buddhist asks what kind of God he is who has created a world full of sufferings. In the authoritative Madhyamaka text Madhyamakaridaya$k \bar{a} r i k \bar{a}$ with the Tarkajvala commentary (both currently attributed to Bhavya, sixth century A.D.) Iśvara is also described (in view of the current state of affairs in the world) as being cruel and unfair. The conclusion drawn from the above is that it is not Iśvara but only karma that can be

\footnotetext{
${ }^{19}$ Reference is to the edition of the standard edition of Jātakas in the Pali Text Society series (the latin number indicates a volume, the Arabic one a page).
} 
held responsible for the creation of the universe.

But we have testimonies of the acute interest on the part of antitheists in the problem of evil also in the texts of philosophical theists themselves. For example, Jayanta Bhațta (most likely the ninth century A.D.), in his great elaboration of the Nyāya system, the very voluminous compendium Nyāyamañjarī, in the section dealing with Íśvara, lists all the main arguments designed to refute the existence of God which were used up to his time. The first one sounds epistemological: God is not perceived and, therefore, also cannot be inferred. The question under discussion is involved in the traditional provocation from the side of Indian anti-theists (Buddhists mostly) who asked about whether God has any reason for acting in the world or not. If $\mathrm{He}$ has, then $\mathrm{He}$ is not self-sufficient and, therefore, not the Lord. If He has not, He then behaves as an insane person. Or maybe He participates in the creations of the world out of compassion? Then, and here the anti-theist triumphs over his opponent, why did He create so much sorrow? And he quotes the verse which runs as follows: "Surely, the heart of the creator of the world was washed by the ambrosia of compassion, for how otherwise could he create it as abounding in suffering and cruelty?!”. To the objection of the generalized theist that a world consisting only of pleasures would not be very long-lived, the antitheist retorts that there is nothing unfeasible for the highest İsvara. And to the theist's objection that İsvara could take into account those good and bad deeds whose residues are located in the numerous souls, his answer sounds again triumphant: "Let then just these deeds be creators of the world - why do we need Iśvara?!". But Indian philosophical theists had also some arguments, and some of them were not too easy to refute.

VI.

There was more then one version of ísvaravāda itself from the ontological point of view. What I prefer to call its "weak" form is the theistic teaching of the classical Yoga, where Íśvara is understood as only the omniscient teacher of mankind willing to lead it to right knowledge and lessen the weight of suffering in rebirths, and serving, at the same time, for ascetics as an object of meditation. I designate this version of Indian 
philosophical theism as a weak one because İśvara is not attributed here any role in the creations and dissolutions of the world, in other words, is bereft of any cosmic functions. The next version could be called "the middle form" of theism, because Ísvara is charged here with cosmic functions and responsibility for sustaining and organizing the empirical world, but this world itself being of a very indefinite ontological status ${ }^{20}$, these functions are also regarded as real only at the level of the empirical truth (vyavahārika) but not of the ultimate one (pāramārthika). This is the version of philosophical theism presented by Advaita-Vedānta. The "strong version" of Indian theism I see in the doctrine of Nyayya and later Vaiśeşika where all the aforementioned cosmic functions of İśvara and his responsibility for the world are regarded as real, in correspondence with the full reality of the universe itself. It is of importance that even the "strong variety" of Indian theism is a weak one if compared with the classical theism of the monotheistic religions, since God in the Indian view can only arrange and rearrange eternal atoms of matter and not create them in the real sense and serves only as a coordinating manager of the law of karma which is also without beginning and of a completely autonomic nature. Bearing in mind these restrictions, let us look at attempts at theodicy which emerged from the second and third versions of Indian theism.

What could be called the theodicy of Ŝankkara, the founder of AdvaitaVedanta (from the seventh to eighth century A.D.), may be divided between two passages of his commentary on the Brahma-sutras (i.e. the Brahmasutrabhashya) II. 1. 34-36 and II. 3. 41-42, where he, in the fashion of the classical commentators, repudiates virtual opponents who, nevertheless, express the views of real ones. In the first of these sections the opponent is a militant anti-theist (in the fashion of the Buddhists, Sāňkhyas and maybe even the materialist Cārvākas) who states that İśvara creates some beings (e.g., gods) as too happy, others as too miserable (e.g., animals) and the third ones as "mediums" (e.g., human beings), and, therefore, should feel affinity for some creatures and hostility for others, which is contrary to his descriptions in the Vedic scriptures. That is why he, having created a world full of suffering, owing to his prejudice

${ }^{20}$ As a product of World Illusion it is not ultimately unreal in the same sense as purely illusory objects and dreams, but by no means properly real as only Brahman is. 
and cruelty, has nothing divine in him. In his reply Ŝankara suggests a very graphic similarity. (Let us not forget that for ancient and medieval Indian philosophers to give a good illustration was the same as to prove any thesis). Iśvara creates living beings by taking into account their virtuous (dharma) and vicious (adharma) qualities and this relieves him of the opponent's incriminations. Grown plants are also unequal owing to the dissimilarity of their seeds (the potencies of future actions), and rain as the general cause of their ripening (Íviara) bears responsibility only for the growing of what was ingrained in them but not for its quality. The opponent objects that the balances of dharma and adharma in souls can form only after the beginning of living creatures' bodily existence, whereas the creation of the world attributed to Iśvara precedes it and therefore he cannot be guided by these balances (consequently, the incrimination of Iśvara in prejudice and cruelty remains valid). Ŝnk kara's reply is that saňsāra itself is beginningless and therefore a series of these balances and bodies is similar to a series of seeds and shoots (a shoot is caused by a preceding seed, the latter by a preceding shoot and so on). To the opponent's question on what grounds one may state that saňsāra is beginningless, the answer is that if it had a beginning and had arisen from nothing, it would prove to be causeless and could come into being again even in the one who has attained salvation from saňsāra (but this is nonsense). The second of Ŝankara's opponents bears features of a Mìmāňsaka. In his view the soul's activity should not depend on Iśvara, for being activated itself by the by the basic and deep affects of consciousness it can have its own experience in activity and therefore no place is left for Íśvara. Besides, in our worldly practice we do not believe that any activity, e.g. ploughing, depends on him. Moreover, Ísvara, in urging souls to the activity that brings about mainly suffering and directing this activity towards unequal results, should be blamed for cruelty and unfairness. Ŝňkara refers to his former examples of seeds and rain. The soul acts on its own even though İ́vara directs its actions. If souls acted only in dependence on İśvara, the Vedic commandments to perform certain actions and to avoid others would be senseless (and an absurdity). Iśvara would have acted for everything else and therefore the performance of even mundane actions by people would have become 
meaningless, but that is not right ${ }^{21}$. So the basic idea of Ŝnankara's theodicy is the acknowledgement of souls' responsibility for all their actions and, correspondingly, the effects of the latter.

The Nayayikas' answers to objections against the existence of Iśvara deriving from the problem of evil were much less eloquent. Jayanta Bhatta, already well known to us, opines that İsvara could work the creations and destructions of the world out of compassion, while the opponents' objections are incorrect. Saňsāra having no beginning, the souls being "pierced" by the effects of their good and bad deeds, and the gates of liberation (mokşa) being insurmountable for them because of the bonds of dharma and adharma, how are they not deserving of compassion?! In addition, in view of these very circumstances Iśvara should provide Hell and other "penitentiaries" (let us not forget that the antitheists referred to these as proofs of his cruelty) for those whose karma is bad to correct their ways. As for the periodic destructions of the worlds (the cycles of pralaya), they are also used by İ́vara to give the selves periodic rests from their labors out of his benevolence ${ }^{22}$. Another great authority, Vācaspati Miśra (the ninth or tenth century A.D.), who wrote in all of the Brahmanic philosophical traditions (except that of Vaiśeşika), in his sub-commentary on the Nyāya-sūtras under the title of Nyāya-vārttikatātparyațīka (IV.I.21), also answers to the question "If Íśvara is merciful, why does He make people suffer?!” that although Iśvara is full of mercy, He has no power to change the natural law (i.e. "the necessity", niyati) that from bad actions bad effects should follow ${ }^{23}$.

${ }^{21}$ The whole of Ŝankkara's dispute with the niriśvaravādin on the topic of evil is reproduced from: Brahmasûtraśāňkarabhāşyam ratnaprabhā-bhāmatī-nyāyanirṇayațikātrayasametam, ed. M.S. Bakre and R.S. Dhupakar (Bombay, 1934), 618-623, 746750 .

${ }^{22}$ For the whole of Jayanta's polemics against the niriśvaravādin, including the problem of evil see: Nyāyamañjarī of Jayanta Bhatța, ed. Mahāmahopadhyāya Gaňgadhāra Śāstrī Tailañga. Pt.1. Benares, 1895 (The Vizianagram Sanskrit Series, 10), 190-204.

${ }^{23}$ Encyclopedia of Indian Philosophies. Vol. II. The Tradition of Nyāya-Vaiśeşika up to Gangeśa, ed. Karl. H. Potter (Delhi: Motilal Banarsidass, 1977), 481. 
VII.

Now, is the proper time for us to give answers to the following two questions: 1) Can the Indian attempts to deliver Íśvara from imputations of cruelty, injustice and, at least, the lack of mercy be rated among the five main patterns of Western theodicy discussed above, or do they constitute a new one? And 2) of what significance for classical theism are the parallels with Indian theodicies which pertain to non-classical versions of philosophical theism?

An answer to 1) may be quite clear: Saňkara’s and Vācaspati Miśra’s attempts at theodicy doubtlessly pertain to pattern (3), that is, the argument from free will, while that of Jayanta Bhatta also pertains to pattern (4), that is, the soul-making defense. Sankkara's very graphic comparison of God with rain, and of the dispositions of souls with seeds, delivers the former from any responsibility for miseries which befall the latter as the results of their bad choices, and the same is true with Vàcaspati Miśra's explanations of God's non-participation in worldly evil. Jayanta Bhatta's treatment of sufferings in hells etc. as a kind of purgatory has a striking similarity with Tertullian's view that Divine punishments are similar to bitter drugs used by doctors for the recovery of patients and that every suffering is intended not against those who suffer but for their good (and such are, in substance, also the views of the earlier Hick ${ }^{24}$ and the current Swinburne). The Indian belief in reincarnation makes it understandable that life in the Indian perspective doesn't confine itself within the span of one birth and one death but is prolonged in further rebirths, so hells and other "penitentiaries" are understood as means of moral education by which God improves beings endowed with reason. While both patterns have as champions religious philosophers of different commitments, the Indian positions are doubtlessly closer to a Platonic than to a Christian mode of thinking. Neither the doctrine of creation (the Hindu philosopher insists that saňsāra is beginningless) nor of sin (man only accumulates dharma or adharma without transgressing the will of the Highest Person) have any correspondences in Indian conceptions.

${ }^{24}$ For the current Hick, who established a new religion with "The Real an sich" as its ontological focus, which is theoretically equidistant from both personal and impersonal symbols but practically much closer to the latter (being in reality one of them), the problem of theodicy cannot be of any relevance. 
In connection with question 2) this means that Indian answers to the challenges deriving from the problem of evil, like those of Islamic and Jewish thinkers (see above) don't expand our Western horizon. This is of much importance, because Indian ísvaravāda is the only tradition of philosophical theism which has no Hellenic roots (in distinction from Islamic and Jewish kalam). And it confirms the view that the main types of Western theodicy remain equally relevant in the intercultural context. So we are justified in considering the patterns of theodicy (3), (4) and (5) as the best ones (see above). In other words, there is no tradition of philosophical theism which would give better explanations of evil in the God-created world than as in some sense conditioned by human sins, in another sense as used by "Divine education" and in a third sense as tolerated because of Divine reasons which are very far from being understandable by created minds. This is already a result of no small importance.

But Indian counterparts of theodicy are valuable for us also in other regards. To begin with, they indirectly show the relevance of those patterns of classical theodicy, viz., (3) and (4), which are more viable than some others. It is of significance, for example, that the Indian mind with all its attention to illusory objects (which have been in some sense the focus of Indian epistemology ${ }^{25}$ ), doesn't regard evil as one of them. Then it is of much significance that having no answer to the question about the origin of evil in the world (for the dogma of a beginningless saňsāra is only a kind of regressus ad infinitum, while the teaching of the Fall, firstly on the part of incorporeal spirits and then of man, gives such an answer however mysterious it $i^{26}$ ) some Indian philosophical theists, Jayanta Bhațta being one of them, felt that there was something corrupt in the universe whereby it would have been unnatural, had it been only happy. Intuitions of such a kind, having some other parallels (e.g., profound

${ }^{25}$ Let's only mention that the topic of illusory objects of perception (when, e.g., one mistakes a rope for a snake or a shell for a piece of silver) made up the whole subject of mithyājn̄anna ("false knowledge") and such mental constructions as the horns of a hare, a celestial flower or the son of a barren woman played a very important role in Indian philosophical argumentation.

${ }^{26}$ It was not too sensible for Western "theology in connection with philosophy" to have tried many times (beginning maybe with Tertullian's De patientia, 5) to discover the secret of why Lucifer fell (in spite of having the best inborn spiritual nature) by inventing purely rational reasons, because the subject itself is inaccessible to reason. 
"feeling of dependence" even if suppressed by the universally recognized doctrines of karma and saňsāra ${ }^{27}$ ), suggest the idea that some theistic archetypes stubbornly sprouting against the thickness of alien layers belong to the initial and genuine elements in the structure of the worldoutlook of even those religions which deviated from monotheism very early while those alien layers (in spite of all their dominance) are indeed alien. If one realizes that the problem of theodicy itself may be of real significance only for the monotheistic world-outlook (where a Personal Creator of the world could have personal responsibility for it), one will not be very far from the idea that the "initial light" of the basic monotheism shone everywhere. And it was sufficiently "strong" (see above), especially if compared with contemporary theological postmodernism (where the religious light has died out completely), e.g., process-theology, whose champions, in opposition to Indian iśvaravādins, preferred to get rid of real attributes of God instead of explaining evil and suffering in the theistic context ${ }^{28}$.

${ }^{27}$ An example is given by Uddyotakara, the author of the Nyāyavārttika (a sub-commentary to the Nyāyasutras) who in response to the sarcastic question of the opponent, i.e. whether God creates the world out of something or out of nothing, says that firstly a man makes an axe out of wood and iron and then with the help of the axe makes lumber, and just so God makes dharma and adharma in the beginning and with their help makes the bodies of man (IV.1.21). Making "dharma and adharma in the beginning", as the instruments for the making of the material world, is almost the same as creating the latter out of nothing.

${ }^{28}$ Though the motive of providing "relief" for the human mind in its attempt to understand evil by "denying" some Divine attributes, omnipotence being one of them, has not, according to my knowledge, been explicitly acknowledged by process-theologians, it is clear that it was also in their purview in their general project of adapting religion to contemporary mankind. Among the avowed enemies of the very problem of theodicy are the representatives of so called feminist theology (Grace Janzen and others). 